\title{
KESADARAN PEMAKAI BAHASA INDONESIA DI ERA TEKNOLOGI
}

\author{
Marsudi, Siti Zahrok, dan Usman Arief
}

\begin{abstract}
Abstrak
Era teknologi informasi dan komunikasi banyak tantangan yang dihadapi bangsa Indonesia, antara lain kesadaran pemakai bahasa Indonesia. Kurangnya kesadaran menghargai bahasa bangsa sendiri menjadi masalah besar bahasa Indonesia. Jika bangsa Indonesia tidak memiliki kesadaran berbahasa yang baik dan benar, bahaya besar bagi kehidupan berbangsa dan bernegara dan akan mengakibatkan bangsa ini akan terjadi disintegrasi dan terombang-ambing oleh bahasa dan budaya bangsa asing, sedangkan bangsa lain telah mempersiapkan diri dengan baik. Perlu diketahui, pemakaian bahasa Indonesia sekarang yang kurang menataati kaidah bahasa Indonesia merupakan indikator bahwa bangsa Indonesia telah mengalami penurunan kesadaran berbahasa Indonesia. Hal ini bisa dilihat di berbagai kesempatan berbahasa, misal acara perdebatan di tevisi yang kurang memperhatikan pemakaian bahasa yang baik dan benar. Oleh sebab itu, kesadaran berbahasa Indonesia harus menjadi perhatian serius oleh pemakai sekaligus pemilik bahasa dan pihak legeslatif, yudikatif, ekskutif, dan terutama aparat pemerintah untuk memberi pemahaman dan teladan. Pemerintah harus tegas untuk menegakkan Undang-Undang Bahasa Indonesia dan bertanggung jawab mengemban amanat untuk memberikan kesadaran berbahasa Indonesia bagi rakyat. Kesadaran ini bermakna bahwa individu yang hidup dan terikat dalam kaidah serta naungan di bawah Negara Kesatuan Republik Indonesia harus memiliki sikap dan perilaku positif yang tumbuh dari kemauan diri yang dilandasasi keikhlasan berbuat demi kebaikan bahasa, bangsa dan negara.
\end{abstract}

Kata kunci: bahasa nasional, kesadaran berbahasa, sikap bahasa.

Era teknologi informasi dan komunikasi yang diiringi dengan berbagai macam produknya menjadikan bahasa Indonesia sebagai sarana komunikasi perlu dipertanyakan dan disadari jati diri serta eksistensinya sebagai bahasa nasional dan bahasa resmi negara. Mengingat, dalam Pembukaan UUD 1945, pengaturan bahasa Indonesia jelas sudah diatur pada pasal 36 bahwa "Bahasa negara adalah bahasa Indonesia" (Alwi, dkk, 2003:1; Halim, 1981:17). Pengaturan itu kemudian diperkuat dengan lahirnya Undang-undang Republik Indonesia Nomor 24 tahun 2009 tentang Bendera, Bahasa, dan Lambang Negara, serta Lagu Kebangsaan. Bahasa Indonesia dalam kaitannya dengan komunikasi di bidang teknologi telah diatur dalam undangundang kebahasaan, yakni Undang-Undang Republik Indonesia No. 24 Tahun 2009, pasal 25, ayat 3 dikemukakan bahwa bahasa Indonesia sebagai bahasa resmi negara sebagaimana dimaksud pada ayat (1) berfungsi sebagai bahasa resmi kenegaraan, pengantar pendidikan, komunikasi tingkat nasional, pengembangan kebudayaan jsh Jurnal Sosial Humaniora, Vol 6 No.2, November 2013 
nasional, transaksi dan dokumentasi niaga, serta sarana pengembangan dan pemanfaatan ilmu pengetahuan, teknologi, seni, dan bahasa media massa (Sugono, 2002:3). Hal itu berarti secara hukum, posisi bahasa Indonesia sudah kuat dan secara yuridis sudah terjamin.

Perkembangan teknologi, terutama teknologi informasi dan komunikasi yang mengglobal telah mempengaruhi kehidupan manusia yang cukup berarti, termasuk eksistensi dan peran bahasa Indonesia sebagai alat komunikasi di bidang teknologi. Seperti telah diketahui bersama bahwa kemajuan teknologi memiliki pengaruh positif dan negatif bagi bahasa Indonesia. Arus informasi dan komunikasi yang mengglobal tidak mungkin untuk dihindari, tetapi harus dihadapi dan diantisipasi untuk menghadapi arus globalisasi sehingga keberadaan peran bahasa Indonesia tidak 'lumpuh' dan tetap tegak sesuai dengan amanat yang ada dalam undangundang.

Berbagai kebijakan kebahasaan pernah dilakukan, tetapi tampak tidak memberikan hasil memuaskan. Bahkan dengan dipaksakannya ragam baku sebagai model bahasa Indonesia yang hendak dipertahankan, justru membuat sebagian besar masyarakat menjauhinya. Kesan yang muncul bukanlah tumbuhnya kesadaran terhadap pemakaian bahasa Indonesia baku sebagai model tunggal yang ditawarkan pemerintah. Di sisi lain, elemen bangsa justru tampak dibelenggu untuk hanya menggunakan satu ragam bahasa yang telah dimonopoli format struktur maupun semantiknya. Tanpa disadari pihak pemerintah, ternyata berbagai bentuk hegemoni kebahasaan tidak menjadikan terkontrolnya berbagai elemen kebangsaan untuk seragam dan bersatu. Namun, hal itu membuat retakan-retakan disintegrasi kebangsaan menjadi semakin menganga. Pada akhirnya untuk masa-masa sekarang ini, realitas dari konsep bahasa Indonesia sebagai bahasa persatuan bukannya tercapai, namun justru tinggal slogan kosong yang sudah dicabut dari referensi simbol asalnya. Oleh karena itu, tulisan ini akan mendeskripsikan permasalahan pemakaian bahasa Indonesia dan perlukah sanksi kesalahan dalam berbahasa Indonesia. 


\section{Kesadaran Berbahasa Indonesia}

Kesadaran secara harfiah berasal dari kata sadar yang berarti merasa, tahu, dan mengerti. Kesadaran berarti keinsyafan atau keadaan mengerti (Kamus Besar Bahasa Indonesia, 1989:765). Kesadaran juga bisa diartikan sebagai kondisi seorang individu memiliki kendali penuh terhadap dorongan internal maupun dorongan eksternal sehingga sadar itu identik dengan mawas diri (awareness). Di samping itu, kesadaran juga meliputi persepsi dan pemikiran yang secara samar-samar disadari oleh individu sehingga akhirnya perhatiannya terpusat. Dalam psikologi, kesadaran didefinisikan sebagai tingkat kesiagaan individu terhadap rangsangan eksternal dan internal. Dengan kata lain, kesiagaan terhadap persitiwa lingkungan, suasana tubuh, memori dan pikiran. Berdasarkan definisi itu, diketahui bahwa kunci penting kesadaran terletak pada kesiagaan dan stimulus (http://sosiologibudaya.wordpress.com/2012/03/01/budaya-dan-kesadaran-budaya/). Jadi, kesadaran berbahasa nasional merupakan pemahaman invidu-invidu sebagai bagian suatu bangsa terhadap bahasa nasionalnya yang secara bersama-sama digunakan, dipertahankan, dan dikembangkan bahasa Indonesia.

Kesadaran berbahasa Indonesia adalah suatu sikap yang dimiliki pemilik dan pemakai berkaitan dengan tanggung jawab hak dan kewajibannya sebagai bangsa (Indonesia). Kesadaran berbahasa Indonesia ini tumbuh setelah memahami sejarah bahasa dan bangsa Indonesia. Dengan adanya kesadaran berbahasa Indonesia akan mampu menumbuhkan semangat untuk berbahasa dan menghindari dan bahkan menolak bertindak 'penjajahan' bahasa asing. Secara tegas, hal tersebut dikemukakan Garvin dan Mathiot (http://www.google.com-sosiolinguistiksikap bahasa) bahwa kesadaran adanya norma bahasa (Awareness Of The Norm) yang mendorong orang menggunakan bahasanya dengan cermat dan santun merupakan faktor yang sangat besar pengaruhnya terhadap perbuatan, yaitu kegiatan menggunakan bahasa (language use). Harus dipahami bahwa bahasa merupakan alat pertukaran informasi. Namun, kadang-kadang informasi yang dituturkan oleh komunikator memiliki maksud terselubung. Oleh karena itu, setiap manusia harus memahami maksud dan makna tuturan yang diucapkan oleh lawan tuturnya. 
Mengenai kesadaran berbahasa, Garvin dan Mathiot (1968 dalam Suwito, 1983:9) menegaskan bahwa kesadaran adanya norma bahasa (Awareness Of The Norm) yang mendorong orang menggunakan bahasanya dengan cermat dan santun merupakan faktor yang sangat besar pengaruhnya terhadap perbuatan yaitu kegiatan menggunakan bahasa (language use). Jika kesadaran berbahasa itu sudah menghilang atau melemah dari diri seseorang atau dari diri sekelompok orang anggota masyarakat tutur, maka berarti sikap negatif terhadap suatu bahasa telah melanda diri atau kelompok orang itu. Ketiadaan gairah atau dorongan untuk mempertahankan kemandirian bahasanya merupakan salah satu penanda sikap negatif, bahwa kesetiaan bahasanya mulai melemah, yang bisa berlanjut menjadi hilang sama sekali.

Jika merujuk pendapat di atas, proses berbahasa seyogianya tidak dapat diberikan batasan-batasan pada setiap diri seseorang. Hak berbahasa harusnya menjadi hak mutlak pada setiap penutur bahasa, termasuk dalam berbahasa Indonesia. Akan tetapi, anomali akan muncul manakala bahasa Indonesia dikaitkan pada sebuah sistem bahasa resmi kenegaraan. Mau tidak mau harus dilakukan pengaturan-pengaturan yang mendasar guna mempertahankan keberadaan bahasa Indonesia. Hal itulah yang berkaitan erat dengan politik kebijakan bahasa Indonesia.

Apabila ditinjau dari kesadaran politik bahasa, bahasa Indonesia merupakan bahasa negara, bahasa nasional, dan sekaligus sebagai identitas dan jati diri bangsa Indonesia. Berarti, bahasa Indonesia seharusnya bahasa yang memiliki karakterkarakter kebahasaan dan keunikan-keunikan tersendiri sebagai pembeda bangsa Indonesia dengan bangsa lain. Bahkan, bahasa Indonesia sebagai kristalisasi pemikiran-pemikiran orang Indonesia. Melalui bahasa Indonesia, cara berpikir, bertutur kata, dan bertindak akan tercermin pada setiap warga Indonesia. Bersatunya pengakuan bahasa Indonesia sebagai bahasa nasional dan pemakaian berbahsa Indonesia dengan baik dan benar merupakan wujud nyata bahwa bangsa Indonesia sebagai pemilik bahasa Indonesia benar-benar memiliki kesadaran berbahasa Indonesia.

Bahasa Indonesia sebagai bahasa nasional yang berfungsi sebagai alat komunikasi mempunyai peran sebagai penyampai informasi. Kebenaran berbahasa 
akan berpengaruh terhadap kebenaran informasi yang disampaikan. Berbagai fenomena yang berdampak buruk pada kebenaran berbahasa harus disesuaikan dengan kaidahnya, yaitu berbahasa Indonesia yang baik dan benar.

Berbahasa Indonesia dengan baik dan benar mempunyai beberapa konsekuensi logis, yakni pemakaiannya terkait dengan situasi dan kondisi. Pada kondisi tertentu, yaitu pada situasi formal penggunaan bahasa Indonesia yang benar menjadi prioritas utama. Penggunaan bahasa seperti ini sering menggunakan bahasa baku. Kendala yang harus dihindari dalam pemakaian bahasa baku antara lain disebabkan oleh adanya gejala bahasa seperti interferensi, integrasi, campur kode, alih kode dan bahasa gaul yang tanpa disadari sering digunakan dalam komunikasi resmi. Hal ini mengakibatkan bahasa yang digunakan menjadi tidak baik. Berbahasa yang baik yang menempatkan pada kondisi tidak resmi atau pada pembicaraan santai tidak mengikat kaidah bahasa di dalamnya.

\section{Pemakai Bahasa Indonesia di Berbagai Kalangan}

Kedudukan bahasa Indonesia sebagai bahasa resmi negara dan bahasa nasional semakin melemah. Melemahnya kedudukan ini dapat disaksikan pada pemakai bahasa oleh para cerdik cendekia, aparat pemerintah (penguasa), dan pemuda saat ini. Tidak sedikit pemakai bahasa Indonesia berdalih bahwa berbahasa itu yang terpenting adalah lawan berbicara dapat memahami informasi yang disampaikan dan tidak harus menggunakan bahasa yang baik dan benar sebagaimana yang diatur dalam kaidah bahasa Indonesia. Sebenarnya, apakah hakikat bahasa itu? Menurut Chaer dan Leonie (2004:11) "bahasa adalah sebuah sistem. Artinya, bahasa dibentuk oleh sejumlah komponen yang berpola secara tetap dan dapat dikaidahkan". Banyak orang tidak terlalu memperhatikan bahasa karena bahasa memang telah melekat pada diri kita sejak lahir, yakni sama halnya ketika kita tidak memperhatikan saat bernafas. "Para linguis struktural menganggap bahwa bahasa sebagai sekedar bunyi yang bersistem. Akan tetapi, kini orang memandang bahwa bahasa itu bukan sekedar bunyi, melainkan sebagai fungsinya yaitu alat komunikasi” (Sumarsono, 2011:18). 
Bagaimana kesadaran pemakai bahasa Indonesia di kalangan pejabat eksekutif, legeslatif, dan yudikatif, generasi muda, dan terutama para pengemban intelektual? Pertanyaan ini tidak hanya layak disampaikan, tetapi harus dipertanyakan kesadaran dan kecintaannya terhadap bahasa Indonesia. Mempertanyakan kesadaran dan kecintaan ini didasarkan atas rendahnya kesadaran menggunakan bahasa Indonesia yang baik dan benar pada masyarakat Indonesia. Jika diperhatikan, bahkan didata, banyak sekali pejabat di atas yang menggunakan bahasa asing, terutama bahasa Inggris, dalam wawancara atau pidatonya, meskipun bahasa asing tersebut telah mempunyai padanan dalam bahasa Indonesia. Dalam hal ini, Koentjaraningrat (dalam Chaer, 1993:16-17) menegaskan bahwa sikap sebagian besar kita suka menyepelekkan bahasa Indonesia memang sangat memprihatinkan. Sikap ini sebenarnya merupakan cerminan sifat-sifat negatif bangsa Indonesia. Sebenarnya, kedudukan bahasa Indonesia amatlah tinggi dan strategis. Hal ini karena bahasa adalah sebagai alat pemersatu. Indonesia yang memiliki suku, adat istiadat, serta bahasa daerah yang beragam dapat disatukan dengan bahasa Indonesia. Kondisi bangsa Indonesia sulit dibayangkan jika tidak ada bahasa pemersatu.

Bagi penguasa, bahasa dapat digunakan sebagai alat untuk melanggengkan kekuasaannya. Untuk menguasai kekuasaan (pikiran) rakyat diperlukan alat komunikasi yang dapat menjangkau semua lapisan masyarakat. Dalam bahasa politik, bahasa penguasa dapat dimanfaatkan untuk membujuk dan merayu serta diajak melakukan tindakan-tindakan tertentu demi mencapai tujuan dan kepentingan pribadi penguasa. Hal ini seperti dikatakan oleh Khaidir Anwar (1984:59) bahwa bahasa politik dapat mencapai kehalusan yang tinggi, yaitu dapat membungkus yang busuk menjadi tidak busuk, yang jelek menjadi baik, dan ancaman dinyatakan dengan halus dan beradab.

Penggunaan bahasa Indonesia yang baik dan benar di kalangan penguasa dan cerdik cendekia kurang menggembirakan. Mengingat, penggunaan bahasa yang baik dan benar para penguasa dan cerdik cendekia ini akan menjadi teladan baik bagi rakyat. Akan tetapi, saat ini banyak penguasa di negeri ini yang kurang dan bahkan belum dapat menggunakan bahasa Indonesia yang baik dan benar sehingga 
berbahasa Indonesia para penguasa dan cerdik cendekia ini belum dapat dijadikan teladan. Pada hal, penyebarluasan konsep-konsep iptek harus dilakukan dengan menggunakan bahasa Indonesia (Alwi, 2000:95). Di sisi lain, sebagai masyarakat Indonesia yang paternalistik, masyarakat Indonesia cenderung melihat perilaku pemimpin untuk dijadikan pedoman serta panutan dalam berbahasa Indonesia. Secara tegas, Ramadian (1995:50) mengatakan bahwa para tokoh masyarakat, seperti cendekiawan, budayawan, aparatur pemerintah, dan ulama sangat dipercayai masyarakat, baik tindak-tanduk, cara berbicara, isi pembicaraan, dan bahasa yang yang digunakannya. Hal ini dapat ditemukan dalam pernyataan penguasa, seperti "Bangsa Indonesia segara mengejar ketertingalan dari bangsa-bangsa yang sudah mengalami kemajuan”. Pada hal pernyataan tersebut sangat tidak tepat dan seharusnya adalah "Bangsa Indonesia segara mengejar kemajuan dari bangsabangsa yang sudah mengalami kemajuan”.

Bangsa Indonesia sebagai pemilik dan pemakai bahasa Indonesia terutama para pejabat negara mengetahui bahwa penggunaan bahasa Indonesia telah diatur dalam UU 24/2009 yang memuat berbagai ketentuan yang mewajibkan penggunaan bahasa Indonesia, salah satunya sebagaimana dimuat dalam Pasal 28 yang menyatakan, "Bahasa Indonesia wajib digunakan dalam pidato resmi Presiden, Wakil Presiden, dan pejabat negara yang lain yang disampaikan di dalam atau di luar negeri". Sementara itu, Pasal 32 UU 24/2009 menyatakan," (1) Bahasa Indonesia wajib digunakan dalam forum yang bersifat nasional atau forum yang bersifat internasional di Indonesia; (2) Bahasa Indonesia dapat digunakan dalam forum yang bersifat internasional di luar negeri" Rekomendasi tersebut sebenarnya menekan para pejabat negara di bumi pertiwi ini untuk konsekuen melaksanakan Undang-Undang 24/2009.

Saat ini bahasa Indonesia semakin kehilangan perannya di negeri sendiri. Hal ini disebabkan regulasi yang mengatur kewajiban menggunakan bahasa Indonesia kurang sempurna. Kekurangsempurnaan UU No.24/2009 tentang penggunaan Bendera, Lambang Negara, dan Bahasa karena tidak memuat sanksi bagi yang melanggar. UU yang tidak dibarengi sanksi secara tegas ini mengakibatkan kesadaran berbahasa yang baik dan benar serta kepedulian terhadap bahasa 
Indonesia menjadi rendah dan bahkan dapat melenyapkan peran bahasa Indonesia sebagai bahasa persatuan, bahasa nasional, dan bahasa resmi negara. Oleh sebab itu, kalangan cerdik cendekia dan penguasa (pejabat/aparat pemerintah) harus menjadi teladan dan dapat menegakkan amanah yang telah tercantum pada undang-undang kebahasaan tersebut.

Di kalangan remaja, bahasa Indonesia memang mengalami perkembangan, tetapi patut sekali disayangkan karena perkembangan bahasa Indonesia di kalangan remaja ini sekarang mulai menyimpang dari tatanan bahasa Indonesia yang baik dan benar. Dikatakan menyimpang karena perkembangannya telah terkontaminasi oleh bahasa asing dan bentuk-bentuk baru yang pembentukannya tidak sesuai dengan kaidah Indonesia, misalnya bonyok merupakan singkatan bokap dan nyokap, yaitu bapak dan ibu. Selain itu, bermunculan ragam-ragam bahasa baru, seperti bahasa pesan pendek dan juga muncul kata lebay, alay, vickynisasi, statusisasi, kontroversi hati dan sebagainya merupakan femonena kebahasaan yang secara perlahan tetapi pasti akan menghancurkan kaidah bahasa Indonesia. Kehadiran bahasa "nyleneh" seperti ini menjadi sebuah virus kebahasaan yang harus ditumpas habis. Bahasa adalah identitas. Bahasa menujukkan tanda "siapa" dan "bagaimana" pemakai bahasa tersebut.

Arus globalisasi dan pesatnya kemajuan teknologi informasi mengakibatkan makin kuat dan intensifnya mempengaruhi eksistensi bahasa Indonesia. Karena sangat lemahnya pengamanan bahasa Indonesia, maka eksistensi bahasa ini mulai tergusur dari kedudukannya. Kenyatan dapat dilihat dalam lirik lagu yang banyak ditemukan bahasa campuran, misalnya salah satu bait pada lirik lagu yang dinyanyikan Sule, yaitu

I can't believe this is happen to me baby...

Aku tidak percaya

I can't believe

All distance to me baby

I can't believe, teu percangkeun.. 
Demikian juga dalam salah satu bait lagu Cherry Belle adalah

mengapa otakku beku tiap memikirkanmu

selalu tubuhku lunglai tiap kau bisikkan cinta

you know me so well

girl i need you, girl i love you, girl i heart you

Padahal, bahasa Indonesia sudah dijunjung tinggi oleh para pemuda 85 tahun lalu, seperti yang tertuang dalam Kongres Sumpah Pemuda. Berarti, kedudukan bahasa Indonesia sedang berada pada kondisi yang mengkhawatirkan keberadaannya sebagai bahasa resmi dan bahasa negara.

Bahasa Indonesia diakui sebagai bahasa pemersatu, kebanggaan dan eksistensi kebangsaan. Akan tetapi faktanya, bahasa yang berkembang sekarang justru bahasa yang tidak sesuai dengan kaidah bahasa sehingga gaya berbahasa para pemuda meracuni kaidah bahasa. Dengan kata lain, fakta-fakta itu menunjukkan halhal yang sebaliknya (paradoksal), atau setidaknya jauh dan tampak menjauh dari bahasa yang ideal. Hal ini merefleksikan bahwa remaja masa kini tidak lagi peduli dengan bahasa Indonesia. Melihat keadaan seperti ini, kita harus berani bertanya dan mempertanyakan "apa yang salah di negeri ini".

Dalam paham paternalistik, pendidik, akademisi, pejabat, penguasa atau pemimpin segala sesuatu yang dilakukan adalah manifestasi kebaikan bagi rakyat atau bawahan. Ucapan dan perilaku kalangan atas dinilai suatu kebaikan sehingga pikiran, ucapan dan perilaku akan diikuti bawahannnya. Budaya semacam itu ternyata masih berlaku di masyarakat Indonesia. Hal ini tidak dapat dipisahkan juga dengan paternalistik dalam bahasa. Jika disimak dengan sungguh-sungguh, banyak akademisi menjadi tamu di negeri sendiri karena dalam komunikasi publik senang menggunakan bahasa yang dicampuri dengan bahasa asing. Kenyataan itu membuktikan bahwa mereka kurang dan bahkan tidak menyadari dan mencintai bahasa bangsa sendiri.

Bahasa Indonesia versi pejabat disusupi oleh keinginan untuk mengaburkan realitas yang terjadi, apalagi jika hal itu mengganggu citra dirinya sebagai pejabat. Bahasa Indonesia yang digunakan sebagian para pejabat sering terkesan samar dan menimbulkan ambiguitas. Menurut pandangan penulis, model berbahasa ini seperti 
sangat mungkin disengaja agar pejabat dapat menafsirkan sebuah peristiwa menurut pendapatnya sendiri. Dengan harapan semua yang disampaikan itu dapat dikategorikan baik-baik saja. Hal itu dilakukan agar pejabat dapat melaporkan pada atasan yang baik-baik juga. Pada titik ini, ungkapan Asal Bapak Senang mendapatkan momentum. Mentalitas seperti inilah banyak mendapatkan tudingan bahwa bahasa Indonesia yang digunakan oleh banyak pejabat mengandung eufemisme.

Eufemisme atau penghalusan bahasa yang digunakan oleh sebagian pejabat berfungsi untuk menyembunyikan realitas "kasar." Ia tak ingin dirinya tercoreng oleh nila setitik rusak susu sebelanga. Eufemisme tidak hanya banyak di zaman orde baru, juga setelah era reformasi sekarang ini. Apalagi, hasrat menjadi pejabat saat ini semakin terbuka lebar, baik di tingkat eksekutif, legislatif, maupun yudikatif. Dengan situasi politik yang kurang didasari logika dan hati nurani seperti itu, katakata penyesuaian harga untuk kenaikan harga, atau saat ini sering disebut pengalihan subsidi, rawan pangan untuk kelaparan, kesalahan administratif untuk korupsi, studi banding untuk jalan-jalan keluar negeri, inefisiensi untuk pemborosan, oknum untuk kesalahan aparat, kesalahan prosedural untuk kebocoran anggaran, dan sederet eufemisme lain yang masuk dalam kamus bahasa pejabat.

Pada mulanya bahasa bersifat netral, bukan milik penguasa. Bahasa tidak berada di simpang kiri atau simpang kanan yang dapat dimanfaatkan untuk kepentingan kekuasaan. Bahasa adalah milik semua. Bahasa memiliki jalan lurus yang tidak menyimpang dan berkelok-kelok. Bahasa hadir dengan takdirnya sebagai alat penutur untuk siapa saja yang memerlukannya dan tidak ada yang berhak mengklaim eksklusivitas bahasa. Sialnya, bahasa Indonesia "dikorupsi" oleh sebagian pihak sebagai alat hegemoni untuk melanggengkan kekuasaannya.

Kesadaran berbahasa Indonesia yang belum baik itu dapat dilihat dalam perilaku individu sebagai rakyat maupun pejabat yang masih menunjukkan tindakan-tindakan yang melanggar kaidah ketepatan dan kebenaran kebahasaan, seperti “Mengenai masalah pengembangan ilmu pengetahuan dan teknologi harus segera kita tingkatkan agar tidak ketinggalan dengan negara-negara maju”. Dua 
pernyataan pada kalimat tersebut sangat aneh atau tidak logis karena justru ilmu pengembangan pengetahuan dan teknologi yang bermasalah itu ditingkatkan bukan ilmu pengetahuan dan teknologi. Masalah-masalah kesadaran berbahasa Indonesia seperti itulah sangat sering dijumpai dalam berbahasa Indonesia di berbagai kegiatan berbahasa Indonesia. Hal ini dilatarbelakangi oleh sikap menggampangkan berbahasa sehingga berakibat tutur bahasa yang digunakan tidak informatif. Masalah seperti ditegaskan oleh Chaer (2010:8) bahwa sifat suka meremehkan tampak pada perilaku berbahasa yang "pokoknya mengerti”. Sikap ini menyebabkan bahasa yang digunakan menjadi asal saja. Mereka tidak memperdulikan bahasa Indonesia yang digunakan itu benar atau salah. Oleh karena itu, ketegasan pemerintah dan berbagai pihak elemen masyarakat yang berkompeten harus berupaya yang lebih intens agar timbul kesadaran masyarkat untuk terus mencintai, bergairah, dan senantiasa menggunakan bahasa Indonesia.

\section{Sanksi Kesalahan Berbahasa}

Proses berbahasa seyogianya tidak dapat diberikan batasan-batasan pada setiap diri seseorang. Hak berbahasa harusnya menjadi hak mutlak pada setiap penutur bahasa, termasuk dalam berbahasa Indonesia. Akan tetapi, anomali akan muncul manakala bahasa Indonesia dikaitkan pada sebuah sistem bahasa resmi kenegaraan. Hal ini harus dilakukan pengaturan-pengaturan yang mendasar guna mempertahankan keberadaan bahasa nasional Indonesia. Hal itulah berkaitan erat dengan politik kebijakan bahasa Indonesia.

Dalam Pembukaan UUD 1945, pengaturan bahasa Indonesia jelas sudah diatur pada pasal 36 bahwa "Bahasa negara adalah bahasa Indonesia". Pengaturan itu kemudian diperkuat dengan lahirnya Undang-undang Republik Indonesia Nomor 24 tahun 2009 tentang Bendera, Bahasa, dan Lambang Negara, serta Lagu Kebangsaan. Hal itu berarti secara hukum, posisi bahasa Indonesia sudah terjamin. Namun, kemauan politik dari pemerintah untuk menata dan menguatkan bahasa nasional sebagai pilar, kepribadian, jati diri, serta sumber daya kebudayaan sampai saat ini belum kelihatan sebagai langkah penyelamatan dari ancaman, baik bangsa Indonesia maupun bahasa asing.

Dalam undang-undang bahasa Indonesia dengan sangat trasparan dijelaskan saat kapan bahasa Indonesia digunakan dan pada situasi apa digunakan bahasa Indonesia. Akan tetapi, persoalan kemudian timbul manakala tidak adanya tindak 
tegas dari pemerintah apabila terjadinya kesalahan berbahasa Indonesia. Tampaknya diperlukan hukum pidana manakala ada warga Indonesia yang tidak menerapkan penggunaan bahasa Indonesia sesuai dengan Undang-undang Nomor 24 tahun 2009 di atas. Jika kesalahan dalam penggunaan bendera Indonesia terjadi kesalahan ukuran, kesalahan bahan pembuatan, dan kesalahan dalam mengubah warna dan corak bendera Indonesia, serta meremehkan bendera Indonesia dengan tindakantindakan yang tidak terpuji tentunya ada hukum pidana dan diproses terhadap orang atau pihak-pihak yang melakukannya. Hal itu tidak jauh berbeda dengan lambang negara Indonesia yang dibuat berbeda dengan yang sebenarnya, ada hukum pidana yang mengaturnya. Misalnya, jika lambang Garuda Pancasila dibuat dengan perbedaan-perbedaan yang mencolok seperti tidak benarnya posisi leher garuda, jumlah setiap helai leher, sayap, dan ekor, seseorang yang demikian dipastikan akan diproses secara hukum. Hal itu juga berlaku pada lagu kebangsaan Indonesia yang dinyanyikan dengan lirik dan nada yang salah pasti akan diproses secara hukum pidana, tetapi pelanggaran berbahasa Indonesia tidak ada hukum pidanya.

Penerapan hukum pidana berbahsa nasional belum ditindaklanjuti secara benar manakala adanya kesalahan penggunaan bahasa Indonesia. Walaupun dari aspek perda (peraturan daerah) sudah ada, penerapan hukumnya belum jelas. Tidak ada sanksi yang terlihat apabila bahasa Indonesia digunakan secara tidak benar. Oleh karena itu, penulis setuju apabila ada pemberian pidana, khususnya hal pelanggaran berbahasa Indonesia. Hal ini tergantung bentuk kesalahan yang dilakukan dan sanksi yang diberikan juga bervariasi serta sesuai dengan tingkat pelanggarannya.

Pemberian sanksi itu diperlukan demi menjaga kedudukan dan penggunaan bahasa Indonesia secara benar serta sekaligus sebagai pencegah terkontaminasinya bahasa Indonesia dengan gempuran bahasa-bahasa lain. Tanpa hukum atau sanksi yang tegas dari pemerintah, sampai kapan pun pelanggaran dan kesalahan-kesalahan berbahasa Indonesia akan terus terjadi. Akibatnya, pelanggaran dan kesalahan itu dikhawatirkan dijadikan sebagai satu alasan untuk tidak menggunakan bahasa Indonesia dengan sebenar-benarnya. Akhirnya, saat ini hanya dapat berdoa dan berharap semoga pemakai bahasa Indonesia menyadari bahwa bahasa Indonesia juga salah satu nafas kehidupan bangsa Indonesia. Mari kita membangun kesadaran 
berbahasa Indonesia dari hati yang ikhlas dan bukan karena harus adanya sanksi. Akan tetapi, jika hal itu diperlukan tidak salah juga sepanjang menjaga keutuhan bahasa Indonesia.

\section{Simpulan}

Kesadaran berbahasa Indonesia dengan baik dan benar sangat layak menjadi isu penting di era global bagi bangsa Indonesia. Mengingat, kesadaran pemakai bahasa Indonesia dari berbagai lapisan masyarakat ini sangat patut dipertanyakan karena sangat sering ditemukan pemakai bahasa Indonesia kurang bahkan tidak memperhatikan kaidah-kaidah berbahasa. Perlu diketahui pula bahwa bahasa Indonesia berkedudukan sebagai bahasa resmi kenegaraan, pengantar pendidikan, komunikasi tingkat nasional, pengembangan kebudayaan nasional, transaksi dan dokumentasi niaga, serta sarana pengembangan dan pemanfaatan ilmu pengetahuan, teknologi, seni, dan bahasa media massa. Oleh karena bahasa Indonesia sebagai bahasa nasional dan bahasa resmi negara, bangsa Indonesia sebagai pemilik dan sekaligus pemakai harus menyadari, mencintai, dan setia menjaga bahasa nasional sebagai bahasa persatuan bangsa sebagai kelanjutan perjuangan pemuda yang terumuskan, terkristal, dan diikrarkan dalam Sumpah Pemuda.

Kesadaran berbahasa Indonesia dengan benar penting untuk dilakukan karena dapat meredam emosi, kepentingan pribadi, atau kelompok yang hampir tidak mengenal batas lagi. Menyadari berarti merasa, mengetahui, memahami, menginsafi, dan mau mengerti keadaan diri, orang lain, dan bangsa Indonesia. Sadar terhadap keadaan yang sebenarnya, objektif, dan berpihak pada realitas kehidupan. Sungguh, hari ini, bangsa Indonesia membutuhkan kesadaran yang tinggi dalam memahami realitas dan menentukan cara bertindak, bersikap terhadap realitas kesadaran berbahasa dan berbangsa. Bangsa ini membutuhkan kesadaran dalam diri, kesadaran terhadap sesama, terhadap masa silam, dan kesadaran masa depan.

Tanpa kesadaran nasional, suatu saat nanti, bangsa Indonesia akan berada pada titik kesendirian, menikmati keterpisahan, dan akhirnya bangga dengan kelemahannya. Kesadaran bukanlah keadaan yang pasif melainkan suatu proses aktif untuk mengerti keadaan hari ini kepada keadaan esok. Kesadaran pada akhirnya 
169 - Kesadaran Pemakai Bahasa Indonesia di Era Tehnologi

akan mengarahkan untuk menjalani kehidupan dengan mantap dalam koridor yang benar. Kesadaran pula menjadi ekspresi keberanian untuk berubah pada saat melakukan kesalahan. Kesadaran itulah yang diperlukan bangsa Indonesia. Oleh sebab itu, kemauan politik yang kuat untuk menata dan menguatkan bahasa Indonesia sebagai pilar, kepribadian, jati diri, dan sumber daya kebudayaan sampai saat ini belum terlihat sebagai langkah penyelamatan dari ancaman, baik dari bangsa Indonesia maupun bahasa asing. 


\section{Daftar Pustaka}

Alwi, Hasan, dkk, 2000, Tata Bahasa Baku Bahasa Indonesia, Jakarta: Balai Pustaka.

Alwi, Hasan, 2000, Bahasa Indonesia Pemakai dan Pemakaiannya, Jakarta: Pusat Bahasa.

Anwar, Khaidir, 1984, Fungsi danPeranan Bahasa: Sebuah Pengantar, Yogyakarta: Gajah Mada University Press.

Badan Pengembangan dan Pembinaan Bahasa Kementerian Pendidikan dan Kebudayaan, 2011, Undang-Undang Republik Indonesia Nomor 24 Tahun 2009 tentang Bendera, bahasa, dan Lambang Negara, serta Lagu Kebangsaan, Jakarta.

Halim, Amran, 1981, "Fungsi Politik Bahasa Nasional," Dalam Politik Bahasa Nasional 1, Jakarta: Balai Pustaka.

http://sosiologibudaya.wordpress.com/2012/03/01/budaya-dan-kesadaran-budaya. diunduh 10 November 2013.

Chaer, Abdul, 1993, Pembakuan Bahasa Indonesia, Jakarta: Rineka Cipta.

Chaer, A dan Leonie A, 2004, Sosiolinguistik, Jakarta: Rineka Cipta.

Chaer, Abdul, 2010, Kesantunan Berbahasa Indonesia, Jakarta: Rineka Cipta.

Kridalaksana, Harimurti, 1985. Fungsi dan Sikap Bahasa, Ende: Nusa Indah.

Moeliono, Anton M (penyunting), Kamus Besar Bahasa Indoneia, Jakarta: Balai Pustaka.

Ramadian, 1995, Misi Bahasa Indonesia di Tengah Kehidupan Bangsa, Padang: Angkasa Raya.

Sogono, Dendy, 2002, Mahir Berbahasa Indonesia dengan Benar, Jakarta: Gramedia Pustaka Utama.

Sumarsono, 2011, Sosiolinguistik, Jogjakarta: Penerbit Sabda.

Suwito, 1983, Pengantar Awal Sosiolinguistik Teori dan Problema, Solo: Henary Offset. 